\title{
Channelling Edwin Chadwick: beyond utopian thinking in urban planning policy and health
}

\author{
Stephen J. Corbett \\ School of Public Health, University of Sydney \\ Centre for Population Health, Sydney West Area Health Service \\ Email: stephen_corbett@wsahs.nsw.gov.au
}

\begin{abstract}
Health impact assessment is advanced as a formal means to assess the direct and indirect health impacts of urban planning decisions and processes. It is, however, an intrinsically passive policy device. A more comprehensive and practical policy framework or architecture, reminiscent of that devised by Edwin Chadwick and the sanitary reform movement in 19th Century England, will be necessary to reorient the goals and practices of urban planning.
\end{abstract}

In 1516 Thomas More published Utopia,${ }^{1}$ his vision of an ideal society in which privilege, title and private property had been abolished and the head of state was chosen in representative elections. People lived in spacious, wellventilated houses, and a social safety net prevented the poor from becoming ill and the ill from becoming poor.

Left unchecked, the growth of cities is at the mercy of landholders and speculators with no direct interest in the quality of future urban environments nor in the health of its citizens. Utopian visions of urban form have had and continue to have a role in planning for the future. Ebenezer Howard's Garden Cities of Tomorrow ${ }^{2}$ placed cities in the countryside, distancing populations from polluted and unsanitary town centres. Le Corbusier's cities of tomorrow, with connecting freeways, high-rise apartments and open space, promised efficiency, amenity and access. ${ }^{3}$ In Sydney, the suburb of Bonnyrigg, a privately developed estate, and high-rise public housing in Waterloo and Surry Hills were in the mould of Howard and Le Corbusier respectively.

Just as More's Utopia was transformed into the nightmarish dystopias of Aldous Huxley ${ }^{4}$ and George Orwell, ${ }^{5}$ modern urban planning has had its failures, as Jane Jacobs made plain in Death and Life of Great American Cities: ${ }^{6}$
But look what we have built: low income projects that become worse centres of delinquency, vandalism and hopelessness than the slums they were built to replace; middle income housing which are true marvels of dullness and regimentation, sealed against the buoyancy and vitality of city life; luxury housing that mitigates its inanity with vapid vulgarity, expressways which eviscerate great cities. This is not rebuilding, this is the sacking of cities.

How, in the process of urban development, can we steer a course between the need for a strong contemporary urban vision, the excesses of utopianism and the chaos of unregulated development? Integrated planning recognises that urban development is a highly complex and contested activity that must assimilate the demands of population growth, land ownership and use, natural resource management, transport and infrastructure, environment and sustainability. London, ${ }^{7}$ Melbourne, ${ }^{8}$ Sydney ${ }^{9}$ and South East Queensland ${ }^{10}$ have all produced integrated long-term plans that have grappled with this complexity. While these plans acknowledge the long-term consequences for health of, for example, incompatible land use, they are almost silent on public health questions such as the health and economic impacts of sedentarism and the loss of social cohesion in many of our communities.

How is the proper consideration of the health of future urban populations to get a seat on this runaway train of urban growth? It may be useful to consult the public health archives. Edwin Chadwick was the architect of public policy reform in Victorian England. His manifesto for public health, the Report ... from the Poor Law Commissioners on an Inquiry into the Sanitary Conditions of the Labouring Population of Great Britain, ${ }^{11}$ published in 1842, set the stage for a suite of major reforms. It included most famously the first Public Health Act but also wholesale reforms of local administration and the funeral industry, the training and recruitment of a cadre of Medical Officers of Health, the resolution of technical arguments about the form of London's sewers and the financing of a massive program of public hygiene works. Although argued on the basis of the flawed science of miasmatism, (which postulated that most illness resulted from the inhalation of the effluvia of rotting animal and vegetable matter) it was buttressed by convincing, but still nascent, epidemiological and demographic data.

In contrast, the Healthy Cities movement was prompted by the World Health Organization (WHO) as an embodiment of the newly minted principles of the Ottawa Charter. ${ }^{12}$ It 
set out to engage local government in health development with a special emphasis on health inequalities and urban poverty, the needs of vulnerable groups, participatory governance and the social, economic and environmental determinants of health. Today, over 1200 cities and towns from more than 30 countries in the WHO European Region are Healthy Cities. Now in its fourth phase (2003-2008), the program is focussed on three core themes: healthy ageing, healthy urban planning and health impact assessment. In addition, all participating cities focus on the topic of physical activity and active living.

These two policy approaches represent a polarity in public health policy and practice. The former, a more comprehensive policy architecture which surveys the entire field of urban planning, looking for opportunities for influence and change which would have long-term benefits for health; ${ }^{13}$ the latter a set of principles for achieving a healthier future, poorly articulated with mainstream urban planning and yet important for building a constituency for change, without which any policy will falter.

Perhaps after 20 years of public health advocacy, a more Chadwickian eye needs to be cast over our approaches to urban health reform.

\section{Regulation hard and soft}

Edwin Chadwick's penchant for prescriptive regulation would be unacceptable to governments in the 21st Century. Mandating, for example, health risk assessments of new developments, would be perceived as an unnecessary imposition. There are, however, softer regulatory options that may provide real opportunities for healthy urban planning:

- Emerging opportunities for the inclusion of health in existing compliance standards such as the recently introduced NSW Building Sustainability Index (BASIX) and the foreshadowed subregional planning tool (METRIX).

- Guidance documents, preferably with joint endorsement by health and planning authorities that contain practical and detailed advice about healthy design, eg the Western Australian Planning Commission (WAPC) Liveable Neighbourhoods Code ${ }^{14}$ the National Heart Foundation's Healthy by Design Guide for Local Government, ${ }^{15}$ and under development is the Commonwealth Healthy Spaces And Places: National Planning Guidelines Project. ${ }^{16}$

- Prescribing a consideration of critical health issues in environmental impact statements, eg in NSW

Planning, focus meetings are the juncture in the planning process where the contents of an environmental impact statement are decided.

- Possible regulatory innovation that could benefit food and transport systems, such as tradeable development rights for agricultural land and land near transport.
Translate public health objectives into the language of economics

Increasingly, the costs of some of the direct and indirect health effects of urban air pollution, overweight and obesity and diabetes are being documented. ${ }^{16}$ What would be even more helpful, given the inevitability of population growth and urban expansion, would be estimates of the marginal costs to health of each of the feasible urban development scenarios. Furthermore if there are specific policy objectives, then the costs and benefits of these proposals need careful assessment. For example, the early placement of schools and public transport infrastructure in new developments may establish patterns of mobility and interconnectedness that will have lasting health benefits for the new community. Treasuries are more likely to support costed proposals which may be able to be included in development levies and which deliver short- to medium-term benefits.

\section{Professional training}

Just as Chadwick and his successors created Medical Officers of Health and Environmental Health Officers as the local arbiters and inspectors of public health risk, so we will need to create a cadre of trained professionals for the issue and for the times. The recent example of the upskilling of the private sector in their ability to undertake health assessment of contaminated sites, stimulated by specific requirements in the Contaminated Lands Management Act 1997, suggest that the labour market will respond rapidly if the right demands are included in public health and planning legislation.

\section{Whole of Government action}

The health of current and future communities needs to be a policy consideration at all levels of the planning system, from strategic to regional to local planning. Collaboration across government is vital if this is to be achieved: there have been some recent successes. In the early stages of the rollout of the Sydney Metropolitan Strategy in 2007, it became obvious that a potentially unwelcome outcome might be a rush to develop high-density residential areas along very busy road transport corridors. The Department of Planning has initiated a process to develop, with the agreement of all NSW government agencies, guidance on acceptable air and noise criteria for these kinds of development.

Chadwick was more utilitarian ideologue than utopian, ${ }^{17}$ and as the architect of the workhouse and the revision of the Poor Laws he was for a time dubbed 'the most hated man in England'. After his demise, the Times gloated: 'we would rather take our chances with cholera than be bullied into health by the likes of Mr Chadwick'. And yet on the 150th anniversary of Chadwick's 1848 Public Health Act, the British Medical Journal asserted that its (and his) qualities of imagination and determination are still needed today. ${ }^{18}$ I agree. 


\section{References}

1. More T. Utopia. Cambridge: Cambridge University Press, 2002.

2. Howard E. Garden Cities of Tomorrow. London: Faber and Farber, 1965.

3. Le Corbusier. Cities of tomorrow and their planning. London: Rodker, 1947.

4. Huxley A. Brave new world. London: Chatto and Windus, 1970.

5. Orwell G. 1984. Oxford: Clarendon Press, 1984.

6. Jacobs J. Death and life of great American cities: Random House, 1961.

7. The London Plan. London: Greater London Authority, 2006.

8. Melbourne 2030. Melbourne: Victorian Department of Sustainability and Environment, 2005.

9. Sydney Metropolitan Strategy. Sydney: NSW Department of Planning, 2005.

10. South East Queensland Regional Plan. Brisbane: Queensland Department of Infrastructure, 2005.
11. Chadwick E. Report on the sanitary condition of the labouring population of Great Britain 1842. Edinburgh: Edinburgh University Press, 1965.

12. World Health Organization, Ottawa Charter for Health Promotion. Geneva: WHO, 1986.

13. Corbett SJ. A ministry for the public's health: an imperative for disease prevention in the 21 st century? Med J Aust 2005; 183(5): 254-7.

14. Liveable Neighbourhood Code. Perth: West Australian Planning Commission, 2004.

15. Healthy by design: a planners'guide to environments for active living. Melbourne: National Heart Foundation (Victorian Division), 2004.

16. Healthy Spaces And Places: National Planning Guidelines Project. Canberra: Commonwealth Department of Health and Ageing, 2007.

17. Mackenbach JP. Thomas More, Etienne Cabet and the Paradoxes of Utopian Thinking. Eur J Public Health 2004; 14(2): 113. doi:10.1093/eurpub/14.2.113

18. Alderslade R. The Public Health Act of 1848. BMJ 1998; 317(7158): 549-50.

\section{NSW PUBLIC HEALTH BULLETIN}

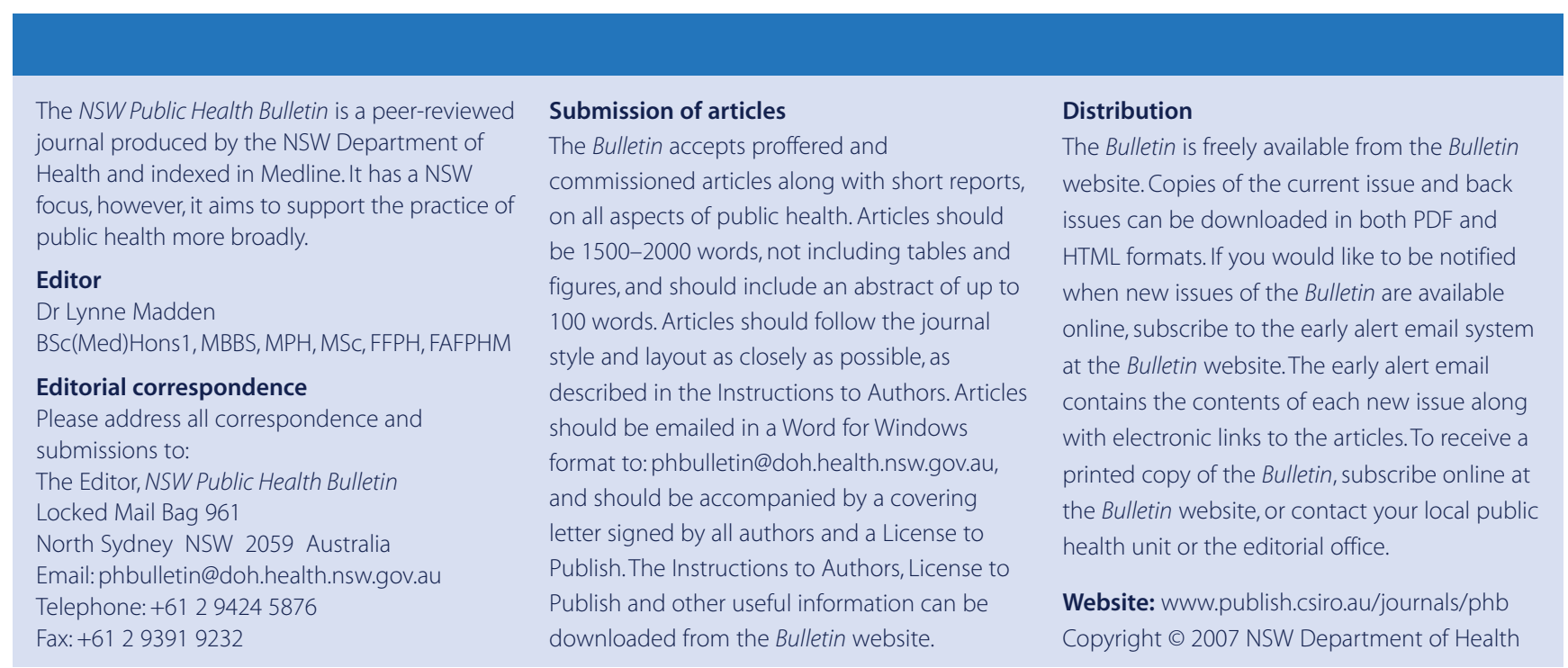

